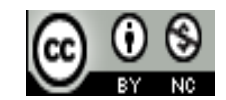

Jurnal Pendidikan Bahasa dan Sastra Indonesia is licensed under

A Creative Commons Attribution-Non Commercial 4.0 International License

\title{
Analisis Sosio-Ekono-Ekolinguistik terhadap Pemertahanan Leksikon Tanaman Tradisonal untuk Bumbu Masak bagi Mahasiswi di Kota Semarang
}

\author{
Wahyudi Joko Santoso \\ Universitas Negeri Semarang \\ E-mail:wahyudibsa@gmail.com
}

\begin{abstract}
Abstrak. Tujuan dari penelitian ini adalah (i) untuk menemukan dan menjelaskan pemeliharaan leksikon tanaman tradisional untuk memasak rempah-rempah oleh siswa perempuan di Kota Semarang, (ii) untuk menemukan dan menjelaskan alasan mereka untuk mempertahankan leksikon tanaman tradisional untuk memasak rempah-rempah, dan (iii ) untuk menemukan dan menjelaskan signifikansi sosial-ekono-ekologisnya. Metode pengumpulan data yang digunakan adalah metode keterampilan dengan teknik dasar memprovokasi dan dilanjutkan dengan teknik pengujian. Teknik analisis data adalah prosentase deskriptifanalitik. Metode penyajian hasil tersebut menggunakan metode informal dan penerapan metode informal ini sekaligus memanfaatkan teknik informal. Hasil penelitian menunjukkan bahwa responden dari Universitas Persatuan Guru Republik Indonesia Semarang (UPGRIS) masih mempertahankan 24 leksikon $(75,00 \%)$ dari 32 leksikon yang diuji. Selanjutnya, Universitas Negeri Semarang (UNNES) merupakan peringkat ke-2, yang masih mempertahankan 14 leksikon (43,75\%). Rangking 3 dan 4 ditempati oleh responden Universitas Katolik (UNIKA) Soegijapranata dan Universitas Negeri Diponegara (UNDIP), masing-masing masih mempertahankan hanya 6 leksikon $(18,75 \%)$. Dengan demikian, rata-rata pemeliharaan leksikon tanaman tradisional untuk bumbu masak (bumbon) untuk siswa perempuan di Kota Semarang hanya mencapai 54,94\% $(24+14+6+6 / 91)$. Dengan demikian, dapat disimpulkan bahwa pemeliharaan leksikon tanaman tradisional untuk memasak rempah-rempah siswa Semarang rendah. Hal ini bisa diartikan bahwa memasak instan telah menggeser bumbu masak tradisional menjadi sekitar 45\%. Arti tanaman "bumbon" oleh responden memiliki beberapa kesamaan, misalnya secara sosial, tanaman ditafsirkan sebagai pembentukan hubungan sosial antara responden dan masyarakat (tetangga, petani, penjual, dan keluarga mereka sendiri). Secara ekonomi, tanaman "bumbon" dimaksudkan untuk menghemat pengeluaran keluarga dan dapat membantu meningkatkan taraf hidup petani dan penjual "bumbon". Secara ekologis tanaman "bumbon" ini dipahami sebagai pelestarian lingkungan dan lingkungan menjadi indah, alami, indah, sejuk, teduh, sehat, cantik, bersih, ramah lingkungan. Selain itu, responden memberi arti lain, seperti memelihara dan memelihara rempah-rempah yang mewarisi rempah-rempah Indonesia, hidup sehat, membuat tanah subur, dan sebagainya.
\end{abstract}

Kata Kunci : pemeliharaan leksikon wanita Semarang, tanaman tradisional, bumbu masak (bumbon), sosiologi, ekonomi, ekologi, linguistik

\section{PENDAHULUAN}

Tanaman tradisional untuk bumbu masak yang telah digunakan oleh suatu komunitas dalam kurun waktu tertentu menggambarkan sebuah peradaban yang tumbuh dan berkembang pada komunitas tersebut. Keberadaannya akan sangat bergantung pada kondisi sosioekologis yang terus berubah. Perubahan budaya (dari budaya tradisional ke budaya modern) atau perubahan ekosistem (dari ekosistem pedesaan ke ekosistem perkotaan) merupakan faktor utama penyebab hilangnya beberapa unsur kebudayaan, khususnya penggunaan tanaman tradisional yang sangat baik dan aman untuk bumbu masak yang sehat, aman, dan murah.

Seiring perkembangan zaman yang terus berubah tersebut, bumbu masak berkembang menjadi dua jenis, yaitu bumbu alami dan bumbu instan yang dibuat secara ekstrak atau campuran beberapa bahan kimia. Pernahkah masyarakat membandingkan untung ruginya menggunakan bumbu alami dengan bumbu instan campuran bahan kimia tersebut? Penetrasi iklan bumbu masak instan luar biasa setiap harinya 
sehingga masyarakat "tidak mau" berpikir ulang lagi karena nilai-nilai tradisional terus tergerus dengan perubahan zaman walaupun membawa resiko kesehatan. Pola pikir masyarakat cenderung praktis, maka pilihan penggunaan bumbu masak instan menjadi pilihan, tidak terkecuali bagi (keluarga) mahasiswi di Kota Semarang.

Di samping itu, ada beberapa faktor yang tidak dapat dikendalikan dalam upaya pelestarian unsur-unsur kebudayaan bagi komunitas tersebut, misal adanya produksi bumbu masak instan secara masif, terkikisnya lahan untuk menaman tanaman bumbu masak tradisional, ketidakmauan untuk menamannya di dalam pot atau dengan model tanaman hidrolik. Faktor-faktor ini bisa saja menyebabkan pergeseran ataupun kepunahan unsur-unsur kebudayaan sehingga unsur-unsur tersebut tidak lagi dipahami dan tidak lagi menjadi pemarkah identitas, khususnya bagi mahasiswi di Kota Semarang. Perubahan sosio-ekologis yang terjadi pada lingkungan mahasiswi di Kota Semarang tersebut diduga berpengaruh pada pembentukan konsepsi leksikal mereka.

Maka penelitian pemertahanan leksikon ini sangat penting untuk dapat mengungkap pemertahanan leksikon mahasiswi Kota Semarang dengan tuntas melalui pendekatan multidisipliner, yakni sosiologi (kemasyarakatan), ekologi (lingkungan), dan linguistik (kebahasaan). Menurut KBBI online (http://kbbi.kata.web.id/leksikon/), leksikon memiliki beberapa pengertian, antara lain (i) kekayaan kata yang dimiliki suatu bahasa, (ii) daftar istilah dalam suatu bidang disusun menurut abjad dan dilengkapi dengan keterangannya, dan seterusnya.

Dari ilustrasi singkat tersebut tampak jelas bahwa masyarakat (mahasiswi), bahasa (leksikon tanaman tradisional untuk bumbu masak), dan lingkungan (Kota Semarang) merupakan satu-kesatuan yang tidak terpisahkan karena ketiganya merupakan tritunggal yang menyatu-padu (unified trinity). Manusia (mahasiswi) pada hakikatnya berbahasa dan pada saat berbahasa manusia menempati ruang (locus) dan waktu (tempus) tertentu. Pemertahanan leksikon tanaman tradisional di sini diartikan sebagai kosa kata tananaman tradisional yang masih diingat/dimiliki/dipahami/digunakan oleh mahasiswi Kota Semarang, seperti jahe, laos, kencur, kunci, bawang merah, bawang putih, ketumbar, dsb.

Di sisi lain, bahasa itu berkembang secara dinamis seiring perkembangan sosial-budaya masyarakat bahasa (speech community) itu sendiri, misal dari budaya tradisional berkembang menjadi budaya modern (baca budaya instan). Demikian juga, ilmu pengetahuan juga ikut berkembang terus-menerus, termasuk kajian bahasa yang digunakan oleh masyarakat bahasa tersebut. Pada tahun 1916-1955-an, kajian bahasa lebih ditekankan pada kajian yang bersifat internal (kajian struktur/ sistem bahasa itu sendiri). Kajian bahasa yang semacam itu dikenal dengan istilah mikrolinguistik. Pascatahun 1955, paradigma kajian bahasa di dunia terus tumbuh berkembang, maka lahirlah kajian bahasa yang bersifat fungsional, yakni mengkaji bahasa dalam perspektif yang lebih luas (makro) sehingga bersifat interdisipliner bahkan multidisipliner. Dalam perpektif ini, kajian bahasa ini tidak hanya berkutat pada kajian bentuk dan makna secara internal tetapi mengkaji bentuk bahasa dan makna secara eksternal. Maka lahirlah kajian bahasa yang dikenal dengan istilah kajian makrolinguistik, yakni mengkaji bahasa dengan mengaitkan faktor-faktor luar bahasa, seperti (i) faktor-faktor sosial, maka lahirlah kajian bahasa secara sosiolinguistik, (ii) suku atau etnik, maka lahirlah kajian bahasa secara etnolinguistik, (iii) kejiwaan, maka lahirlah kajian bahasa secara psikolinguistik, (iv) penggunaan bahasa secara praktis, maka lahirlah kajian bahasa secara pragmatik, (v) lingkungan, maka lahirlah kajian bahasa secara ekolinguistik, faktor sosial dan ekolologi, maka lahirlah sosioekolinguistik, dsb.

Peneliti ekolinguistik dapat membedah maknamakna sosioekologis di balik bahasa, khususnya leksikon, di atas dasar konsep dan landasan teoretis, yaitu (1) bahasa yang hidup dan digunakan itu menggambarkan, mewakili, melukis (merepresentasikan secara simbolik-verbal) realitas di lingkungan, baik lingkungan alam maupun lingkungan buatan manusia (lingkungan sosial-budaya); (2) dinamika dan perubahan bahasa pada tataran leksikon misalnya, seperti yang dikemukakan oleh Lindo dan Bundsgaard (2000: 10-11) (lihat Subiyanto pada http://ejournal.undip.ac.id/index.php/ humanika/article/view/5939.

Selanjutnya, Derni (2008) menulis penelitian berjudul "The Ecolinguistic Paradigm: An Integrationist Trend in Language Study". Penelitian ini dimuat dalam The International Journal of Language Society and Culture. Dalam penelitian ini, disajikan sebuah tren pemersatu dalam studi bahasa. Peneliti menggunakan pendekatan ekolinguistik untuk melihat fenomena studi bahasa yang dapat mempersatukan suatu golongan. Peneliti juga mengungkap hubungan psikologi sosial yang berkaitan dengan ideologi, sosiologi, dan biologi. Tiga hal tersebut saling berhubungan dalam kehidupan. Selain itu, penelitian ini juga mendeskripsikan kombinasi bahasa dalam bidang ekologi, sosiologi, dan biologi. Bahasa menjadi pemersatu dalam entitas kehidupan sosial dan alam.

Berkenaan dengan lingkungan, dewasa ini, salah satu isu yang sangat aktual dan hangat disuarakan oleh berbagai pihak, baik di dalam maupun di luar negeri adalah masalah lingkungan hidup. Betapa tidak, perubahan iklim (climate change) akibat pengrusakan lingkungan berimplikasi pada naiknya suhu udara dan permukaan air laut secara signifikan. Hal itu sangat memengaruhi kualitas dan kuantitas keberlangsungan kehidupan, baik kehidupan flora maupun fauna, termasuk kehidupan manusia dalam berbagai segi kehidupannya: sosial-kultural, politik, ekonomi, kesehatan, berbahasa, dan sebagainya.

Sebelum lingkungan tempat manusia tinggal rusak dan mengawatirkan, pengkajian bahasa yang bertema lingkungan (ecology) hampir tidak terdengar di Indonesia. Namun, setelah lingkungan (bumi) tempat manusia tinggal tidak lagi bersahabat bahkan diambang kritis yang dapat membahayakan kelangsungan hidup, maka pengkajian bahasa secara ekolinguistik mulai diminati oleh peneliti. Terlebih semenjak terbitnya buku The Ecology of Language: Language science and national development (Haugen, 1972) 
di Amerika, maka kajian bahasa dalam perspektif ekolinguistik ini mulai diminati juga oleh peneliti Indonesia. Ekolinguistik adalah suatu disiplin ilmu yang mengkaji lingkungan dan bahasa. Ekolinguistik merupakan ilmu bahasa interdisipliner, menyanding ekologi dan linguistik (Mbete, 2009). Kajian interdisipliner yang mengaitkan ekologi dan linguistik ini sebenarnya sudah diawali pada tahun 1971 ketika pakar ini menciptakan paradigma "ekologi bahasa." Dalam pandangan Haugen, ekologi bahasa adalah kajian tentang interaksi bahasa dan lingkungannya. Berikut kutipan yang menjelaskan maksud tersebut.

Einar Haugen is generally regarded as the founding father of 'language ecology' or 'ecology of language'. In his classic 1971 paper, he suggested that "language ecology may be defined as the study of interactions between any given language and its environment" (http://www.sciencedirect.com/science/article/pii/S 0388000115000352)

Sementara itu, dalam bahasa Prancis, istilah language ecology' digunakan Ecologie linguistique dan Ecolinguistique (Lechevrel, 2009 : 5 dalam al-Gayoni, 2010 :26).

Namun, kajian ini tidak bisa dilepaskan secara sosiologis karena dalam pandangan sosiolinguistik yang mengkaji hubungan masyarakat dan bagaimana masyarakat tersebut mengaturnya untuk tinggal bersama, para sosiolinguis menggunakan konsep-konsep identity, power, class, status, solidarity, acommodation, face, gender, politeness, dsb. (lihat Hudson dalam Wardhaugh, 1988).

Berdasarkan latar belakang masalah di atas, dapat dirumuskan masalah penelitian sebagai berikut. (1) Dalam rangka konservasi tanaman tradisional untuk memasak, leksikon apa saja yang masih dipertahankan oleh mahasiswi di Kota Semarang? (2) Mengapa mereka masih mempertahankan (sejumlah) leksikon tanaman tradisional tersebut dan bagi mereka, apa saja makna sosio-ekologis tanaman tradisional tersebut? (3) Faktor apa saja yang menyebabkan pemertahanan (sejumlah) leksikon tanaman tradisional oleh mahasiswi tersebut berkurang/bertahan secara signifikan?

\section{METODE}

\section{A. Pendekatan}

Penelitian ini bersifat multidisipliner, yakni mengkaji leksikon tanaman tradisional untuk bumbu masak dari tiga perspektif sekaligus, yakni sosiologi, ekologi, dan linguistik. Ketiga perspektif tersebut dapat dijelaskan sebagai berikut.
Sociology
is the
science
of society, social institutions, and social relationships; specifically: the systematic study of the development, structure, interaction, and collective behavior of organized groups of human beings. Ecology is a branch of science concerned

with the interrelationship of organisms and their environments. Linguistics is the study of human speech including the units, nature, structure, and modification of language (https://www.merriamwebster.com/dictionary/sociology)

Di dalam penelitian ini, pendekatan sosiologis digunakan untuk melihat structure, interaction, and collective behavior of organized groups of human beings (struktur interaksi dan perilaku kolektif mahasiswi) di Kota Semarang (lihat Gambar 1). Pendekatan ekologis digunakan untuk melihat the interrelationship of organisms and their environments tempat mahasiswi tinggal. Adapun pendekatan linguistik dipakai untuk melihat units of human speech (leksikon) tanaman tradisional yang masih dipertahankan oleh mahasiswi di Kota Semarang untuk bumbu masak.

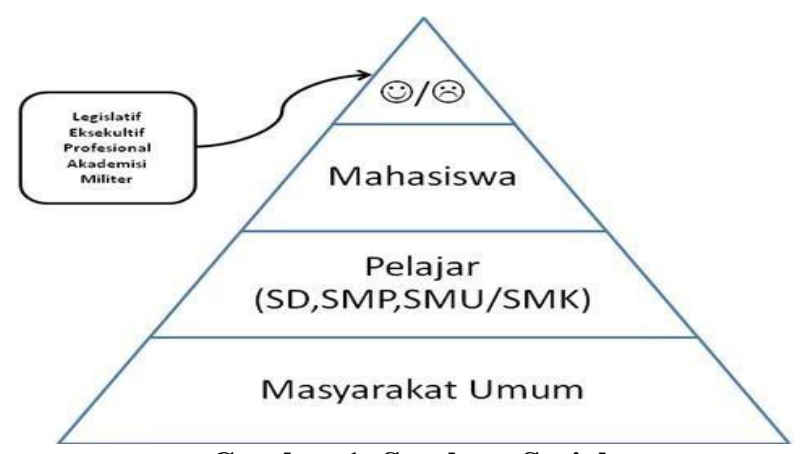

Gambar 1: Struktur Sosial

B. Subjek Penelitian, Penentuan Subjek, dan Objek Penelitian

Subjek penelitian adalah subjek yang dituju untuk diteliti, yakni mahasiswi di Kota Semarang. Dalam penelitian kualitatif, hal yang menjadi bahan pertimbangan utama dalam pengumpulan data adalah pemilihan informan. Pemilihan informan ini digunakan teknik sampling purposive sample. Purposive sample adalah teknik penentuan sampel dengan pertimbangan tertentu (Sugiyono, 2014:85). Pemilihan sampel secara purposive ini akan berpedoman pada syarat-syarat yang harus dipenuhi, seperti (i) pengambilan sampel harus didasarkan atas ciri-ciri, sifat-sifat atau karakteristik tertentu, yang merupakan ciri-ciri pokok populasi, yakni mahasiswi di Kota Semarang dan (ii) subjek yang diambil sebagai sampel benar-benar merupakan subjek yang paling banyak mengandung ciri-ciri yang terdapat pada populasi tersebut, yakni mahasiswi yang masih kuliah aktif dan berasal dari kota dan kabupaten se-eks Karisidenan Semarang, yakni mahasiswi dari 2 perguruan tinggi negeri (UNDIP dan UNNES) dan 2 pertinggian swasta (UPGRIS dan UNIKA SOEGIJAPRANOTO). Adapun objek penelitian ini adalah pemertahanan leksikon oleh mahasiswi di Kota Semarang dan faktor-faktor yang mempengaruhi pemertahanan leksikon tersebut. 


\section{Data dan Sumber Data}

Data penelitian ini berupa satuan-satuan lingual (leksikon) tanaman tradisional dan manfaatnya untuk bumbu masak yang digunakan dalam konteks menanam tanaman tradisonal dan atau menggunakannya untuk memasak. Sumber data penelitian ini diperoleh dari sumber daring http://axcelipa5kelautan.blogspot.co.id/2015/11/25-manfaatdan-kegunaan-bumbu-dapur.html yang diunduh pada tanggal 25 Februari 2017.

\section{Metode dan Teknik Penyediaan Data}

Sementara itu, metode penyediaan data yang digunakan adalah metode cakap dengan teknik dasar teknik pancing yang dilanjutkan dengan teknik tansemuka (teknik tes) (Sudaryanto, 1993).

\section{E. Metode dan Teknik Analisis Data}

Metode analisis yang dipakai adalah metode deskriptif-analitik, yakni mendeskripsikan data sesuai dengan fakta yang ditemukan di lapangan, dilanjutkan analisis dan secara teknis dihitung besarnya persentase pemertahanan leksikon. Penggunaan metode ini merupakan ciri khas penelitian kualitatif, yakni antara lain bersifat naturalistic inquiry: mempelajari situasi dunia nyata secara alamiah, tidak melakukan manipulasi; terbuka pada apapun yang timbul, bersifat induktif, mengutamakan pemaknaan, dan sebagainya (dapat dilihat pada http://www.dosenpendidikan.com/metode-penelitian-

kualitatif-pengertian-menurut-para -ahli-ciri-tujuan/.) Selanjutnya, hasil penghitungan diinterpretasi untuk memberikan pemaknaan dan alasan pemertahanan leksikon tanaman tradisional untuk bumbu masak (bumbon) tersebut.

\section{F. Metode dan Teknik Penyajian Hasil Analisis}

Sudaryanto (1993) membedakan metode penyajian hasil analisis data menjadi dua, yaitu metode formal dan informal. Metode penyajian formal adalah penyajian hasil analisis dengan tanda dan lambang yang dalam penerapannya dilakukan dengan bagan-bagan dan tabeltabel. Adapun metode penyajian informal adalah metode panyajian dengan kata-kata biasa (natural language) walaupun dengan terminologi yang sifatnya teknis. Metode yang akan dimanfaatkan adalah metode jenis kedua, yaitu metode informal dan pelaksanaan dari metode informal tersebut sekaligus merupakan penggunaan teknik informal itu sendiri.

\section{HASIL DAN PEMBAHASAN}

A. Pemertahanan Tanaman Tradisional ke-4 Perguruan Tinggi UPGRIS, UNNES, UNIKA, UNDIP

Ada 32 tanaman tradisional untuk bumbu masak (bumbon) yang diteskan kepada 91 responden, yakni UNNES (21 mahasiswi), UPGRIS (30 mahasiswi), UNIKA (20 mahasiswi), dan UNDIP (20 mahasiswi). Ke-32 tanaman bumbon tersebut adalah jahe, lengkuas, kunyit, kencur, temu lawak, temu kunci, ketumbar, lada, jinten, adas, andaliman, pala, keluwak, kemiri, daun jeruk purut, daun salam, kemangi, seledri, daun kari, daun bawang merah, daun bawang putih, serai, kapulaga, asam jawa, jeruk nipis, jeruk purut, bawang merah, bawang putih, bawang bombai, kayu manis, cengkih, dan cabai merah keriting.

Pada Tabel 1 di bawah ini dapat diketahui bahwa responden yang tertinggi mempertahankan 32 leksikon tanaman tradisional untuk bumbu masak (bumbon), yakni UPGRIS dengan rata-rata persentase sebesar $79.00 \%$. Peringkat kedua diduduki oleh responden dari UNNES dengan rata-rata persentase sebesar $62.48 \%$. Peringkat ketiga ditempati oleh responden dari UNIKA dengan rata-rata persentase sebesar $30.96 \%$. Peringkat terakhir diduduki oleh responden dari UNDIP dengan rata-rata persentase terendah, yakni sebesar $27.25 \%$. Perhitungan itu didasarkan pada banyaknya bumbon yang dijawab dengan tepat oleh masingmasing responden, dibagi jumlah responden $\mathrm{x}$ jumlah bumbon. Jumlah masing-masing yang berhasil dijawab mahasiswi di UPGRIS sebesar 2528.14, UNNES sebesar 1993.80, UNIKA sebesar 990.73, dan UNDIP sebesar 871.98. Untuk jelasnya, perhatikan Tabel 1 berikut ini.

Tabel 1: Hasil Rata-rata Pemertahanan Tanaman Tradisional ke-4 Perguruan Tinggi UPGRIS, UNNES, UNIKA, UNDIP

\begin{tabular}{|c|l|r|r|}
\hline NO & \multicolumn{1}{|c|}{ Perguruan Tinggi } & \multicolumn{2}{|c|}{ Jumlah } \\
\cline { 3 - 4 } & & Angka & $\begin{array}{c}\text { Skor } \\
(\%)\end{array}$ \\
\hline 1. & UPGRIS & 2528.14 & 79.00 \\
\hline 2. & UNNES & 1993.80 & 62.48 \\
\hline 3. & $\begin{array}{l}\text { UNIKA } \\
\text { SOEGIJOPRANOTO }\end{array}$ & 990.73 & 30.96 \\
\hline 4. & UNDIP & 631.98 & 27.25 \\
\hline 5. & Rata-rata & 638.65 & 49.92 \\
\hline
\end{tabular}

Secara sosiologis, Tabel 1 di atas dapat dimaknai bahwa mahasiswi yang berada dalam lapisan masyarakat level 2 (di bawah eksekutif, legislatif, profesional, akademisi, militer) berada dalam struktur sosial yang cukup baik di dalam masyarakat (lihat Gambar 1). Dalam kehidupan sehari-hari, mahasiswi berinteraksi dengan masyarakat sekitar sehingga mereka memiliki perilaku sosial secara kolektif di Kota Semarang. Dalam konteks ini, mereka berperilaku tidak mengenal lagi sebagian besar (hampir $50 \%$ ) leksikon tanaman tradisional untuk bumbu masak walaupun mereka kelak akan berumah tangga dan memasak untuk keluarga mereka. Secara ekologis, mahasiswi berinteraksi dengan lingkungan mereka tempat mahasiswi tinggal, baik itu lingkungan bioti maupun abioti. Tabel 1 di atas menunjukkan pula adanya hubungan yang tidak "harmonis" lagi antara mahasiswi (calon ibu rumah tangga) dengan lingkungan (bahasa: leksikon tanaman bumbon) yang ada di sekitar mereka, misal di supermarket, di pasar, 
di warung, di kebun/sawah/ladang, dan sebagainya. Secara linguistik, khususnya leksikon tanaman tradisional untuk bumbon, tinggal 49,92\% leksikon beserta makna denotatif dan makna referensialnya yang masih dipertahankan oleh mahasiswi di Kota Semarang.

B. Makna Sosial-Ekonomis-Ekologis Leksikon Tanaman Tradisional bagi Mahasiswi Kota Semarang

Di dalam bagian ini akan dibahas makna sosial-ekonomisekologis tanaman tradisional bagi mahasiswi Kota Semarang, yakni mahasiswi UNNES, mahasiswi UPGRIS, mahasiswi UNIKA SOEGIJAPRANATA, dan mahasiswi UNDIP. Selanjutnya, perhatikanlah Tabel 2 berikut ini: makna sosial-ekonomis-ekologis tanaman tradisional bagi mahasiswi Kota Semarang.

Tabel 2: Makna Sosial, Ekonomis, Ekologis

\begin{tabular}{|c|c|c|c|}
\hline \multirow[t]{2}{*}{ Univ. } & \multicolumn{3}{|c|}{ Makna } \\
\hline & Sosial & Ekonomis & Ekologis \\
\hline UPGRIS & $\begin{array}{l}\text { untuk menjalin } \\
\text { berinteraksi } \\
\text { dengan orang } \\
\text { lain (tetangga, } \\
\text { penjual, dan } \\
\text { petani) }\end{array}$ & $\begin{array}{l}\text { tanaman } \\
\text { bumbon } \\
\text { dapat } \\
\text { menghemat } \\
\text { uang belanja } \\
\text { dan } \\
\text { peningkatan } \\
\text { ekonomi } \\
\text { petani, } \\
\text { penjual, dan } \\
\text { keluarga }\end{array}$ & $\begin{array}{l}\text { penamaan } \\
\text { tanaman } \\
\text { bumbon dapat } \\
\text { melestarikan } \\
\text { lingkungan } \\
\text { dan } \\
\text { lingkungan } \\
\text { menjadi } \\
\text { teduh, cantik, } \\
\text { asri, ramah, } \\
\text { alami, indah, } \\
\text { bersih }\end{array}$ \\
\hline UNNES & $\begin{array}{l}\text { untuk menjalin } \\
\text { relasi sosial } \\
\text { dengan orang } \\
\text { lain (tetangga, } \\
\text { penjual, dan } \\
\text { petani) }\end{array}$ & $\begin{array}{l}\text { tanaman } \\
\text { bumbon } \\
\text { dapat } \\
\text { menghemat } \\
\text { uang belanja } \\
\text { dan } \\
\text { peningkatan } \\
\text { ekonomi } \\
\text { petani dan } \\
\text { penjual }\end{array}$ & $\begin{array}{l}\text { penamaan } \\
\text { tanaman } \\
\text { bumbon dapat } \\
\text { melestarikan } \\
\text { lingkungan } \\
\text { dan } \\
\text { lingkungan } \\
\text { menjadi asri, } \\
\text { alami, indah, } \\
\text { sejuk, } \\
\text { rindang, } \\
\text { sehat, dan } \\
\text { sebagainya }\end{array}$ \\
\hline UNIKA & $\begin{array}{l}\text { untuk } \\
\text { memperhatikan } \\
\text { tradisi keluarga } \\
\text { karena } \\
\text { keluarga masih } \\
\text { menggunakan }\end{array}$ & $\begin{array}{l}\text { tanaman } \\
\text { bumbon } \\
\text { dapat } \\
\text { menghemat } \\
\text { uang belanja } \\
\text { (murah) }\end{array}$ & $\begin{array}{l}\text { penamaan } \\
\text { tanaman } \\
\text { bumbon dapat } \\
\text { melestarikan } \\
\text { rempah- } \\
\text { rempah } \\
\text { (tanaman } \\
\text { bumbon), } \\
\text { membuat } \\
\text { ramah } \\
\text { lingkungan, } \\
\text { dijadikan }\end{array}$ \\
\hline
\end{tabular}

\begin{tabular}{|c|c|c|c|}
\hline & & & obat herbal \\
\hline UNDIP & $\begin{array}{l}\text { membantu } \\
\text { orang lain } \\
\text { (penjual dan } \\
\text { petani), menjadi } \\
\text { sarana } \\
\text { berinteraksi } \\
\text { dengan petani } \\
\text { dan penjual, } \\
\text { menghargai } \\
\text { petani }\end{array}$ & $\begin{array}{l}\text { menghemat } \\
\text { uang belanja } \\
\text { dan } \\
\text { peningkatan } \\
\text { ekonomi } \\
\text { petani dan } \\
\text { penjual }\end{array}$ & $\begin{array}{l}\text { melestarikan } \\
\text { lingkungan } \\
\text { dan } \\
\text { lingkungan } \\
\text { menjadi } \\
\text { alami, baik } \\
\text { bagi } \\
\text { kesehatan, } \\
\text { memudahkan } \\
\text { mendapatkan } \\
\text { obat herbal, } \\
\text { dan tidak } \\
\text { merusak } \\
\text { lingkungan } \\
\text { (aman) }\end{array}$ \\
\hline
\end{tabular}

Dengan melihat Tabel 2 di atas dapat diketahui bahwa terdapat banyak kesamaan dalam memaknai tanaman tradisional untuk bumbu masak (bumbon), misal secara sosial, tanaman tradisional tersebut dapat menjalin relasi sosial yang baik antara responden dengan masyarakat (petani, penjual, dan keluarga sendiri). Secara ekonomis, tanaman bumbon itu dapat menghemat uang belanja keluarga dan dapat membantu/meningkatkan taraf hidup petani dan penjual bumbon. Secara ekologis, tanaman bumbon dapat melestarikan lingkungan hidup (tanaman tradisonal untuk bumbu masak) dan lingkungan menjadi semakin lebih asri, alami, indah, sejuk, rindang, sehat, cantik, bersih, ramah lingkungan, dan tanaman tersebut dapat dimanfaatkan sebagai obat herbal. Artinya tanaman tersebut multiguna: sebagai bumbu msak dan obat herbal yang tentu saja lebih sehat, aman, dan murah.

C. Alasan Pemertahanan Leksikon Tanaman Tradisional bagi Mahasiwi Kota Semarang

Di dalam bagian ini akan dibahas berbagai alasan pemertahanan tanaman tradisional bagi mahasiswi Kota Semarang: mahasiswi UNNES, mahasiswi UPGRIS, mahasiswi UNIKA SOEGIJAPRANATA, dan mahasiswi UNDIP. Pertama, Tabel 3 berikut ini adalah rekap alasan pemertahanan tanaman tradisional bagi mahasiswi UNNES.

Untuk memperjelas faktor-faktor pemertahanan leksikon tanaman tradisional untuk bumbu masak (bumbon), simaklah Tabel 3 berikut.

Tabel 3: Faktor-faktor Pemertahanan Leksikon Tanaman Tradisional

\begin{tabular}{|c|c|c|c|c|}
\hline \multirow[t]{2}{*}{$\mathrm{NO}$} & \multicolumn{4}{|c|}{$\begin{array}{c}\text { Faktor-faktor Pemertahanan Leksikon Tanaman } \\
\text { Tradisional }\end{array}$} \\
\hline & UPGRIS & UNNES & UNIKA & UNDIP \\
\hline 1. & $\begin{array}{l}\text { alami, } \\
\text { tradisional } \\
\text { dan mudah } \\
\text { didapatkan }\end{array}$ & terbiasa & sehat & budidaya \\
\hline 2. & $\begin{array}{l}\text { murah dan } \\
\text { mudah } \\
\text { didapatkan }\end{array}$ & $\begin{array}{l}\text { alami dan } \\
\text { enak }\end{array}$ & $\begin{array}{l}\text { sehat dan } \\
\text { enak }\end{array}$ & $\begin{array}{l}\text { alami, } \\
\text { sehat, } \\
\text { murah }\end{array}$ \\
\hline
\end{tabular}


Gura Perdecuren Bahasa dan Sastra Yndonesia

\begin{tabular}{|c|c|c|c|c|}
\hline 3. & $\begin{array}{l}\text { yang } \\
\text { utama buat } \\
\text { masakan }\end{array}$ & $\begin{array}{l}\text { turun- } \\
\text { temurun }\end{array}$ & $\begin{array}{l}\text { sehat dan } \\
\text { enak }\end{array}$ & $\begin{array}{l}\text { sehat dan } \\
\text { enak }\end{array}$ \\
\hline 4. & $\begin{array}{l}\text { pemertaha } \\
\text { nan rasa } \\
\text { asli }\end{array}$ & $\begin{array}{l}\text { mudah } \\
\text { diingat }\end{array}$ & $\begin{array}{l}\text { asli } \\
\text { Indonesia }\end{array}$ & $\begin{array}{l}\text { dekat } \\
\text { kebun, } \\
\text { murah, } \\
\text { mudah } \\
\text { didapat }\end{array}$ \\
\hline \multirow[t]{9}{*}{5.} & $\begin{array}{l}\text { pemertaha } \\
\text { nan } \\
\text { bumbu } \\
\text { tradisional }\end{array}$ & $\begin{array}{l}\text { pemertaha } \\
\text { nan bumbu } \\
\text { tradisional }\end{array}$ & enak & $\begin{array}{l}\text { bermanfaat } \\
\text { bagi } \\
\text { kesehatan } \\
\text { sangat } \\
\text { positif dari } \\
\text { pada } \\
\text { bumbu } \\
\text { instan }\end{array}$ \\
\hline & $\begin{array}{l}\text { sering } \\
\text { saya } \\
\text { gunakan }\end{array}$ & $\begin{array}{l}\text { sering saya } \\
\text { gunakan }\end{array}$ & terbiasa & $\begin{array}{l}\text { enak dan } \\
\text { sehat }\end{array}$ \\
\hline & $\begin{array}{l}\text { dapat } \\
\text { dijumpai } \\
\text { dalam } \\
\text { kehidupan } \\
\text { sehari-hari }\end{array}$ & $\begin{array}{l}\text { dapat } \\
\text { dijumpai } \\
\text { dalam } \\
\text { kehidupan } \\
\text { sehari-hari }\end{array}$ & $\begin{array}{l}\text { bermanfaat } \\
\text {, murah, \& } \\
\text { mudah } \\
\text { diperoleh }\end{array}$ & $\begin{array}{l}\text { enak dan } \\
\text { orisinil }\end{array}$ \\
\hline & $\begin{array}{l}\text { rasa lebih } \\
\text { enak dan } \\
\text { mudah } \\
\text { didapatkan }\end{array}$ & $\begin{array}{l}\text { rasa lebih } \\
\text { enak dan } \\
\text { mudah } \\
\text { didapatkan }\end{array}$ & kebiasaan & $\begin{array}{l}\text { murah, } \\
\text { mudah } \\
\text { didapat, } \\
\text { rasa khas }\end{array}$ \\
\hline & $\begin{array}{l}\text { rasa } \\
\text { enak/tidak } \\
\text { hambar }\end{array}$ & $\begin{array}{l}\text { rasa } \\
\text { enak/tidak } \\
\text { hambar }\end{array}$ & $\begin{array}{l}\text { pemertaha } \\
\text { nan budaya } \\
\text { kuliner }\end{array}$ & $\begin{array}{l}\text { kebutuhan, } \\
\text { murah, } \\
\text { mudah } \\
\text { didapat }\end{array}$ \\
\hline & $\begin{array}{l}\text { mudah } \\
\text { diucapaka } \\
\text { n dan lebih } \\
\text { mudah } \\
\text { dipahami }\end{array}$ & $\begin{array}{l}\text { mudah } \\
\text { diucapakan } \\
\text { dan lebih } \\
\text { mudah } \\
\text { dipahami }\end{array}$ & & $\begin{array}{l}\text { kekayaan } \\
\text { bangsa, } \\
\text { kaya } \\
\text { vitamin, } \\
\text { enak }\end{array}$ \\
\hline & $\begin{array}{l}\text { mudah } \\
\text { didapat } \\
\text { dan dapat } \\
\text { memberik } \\
\text { an rasa } \\
\text { tersendiri }\end{array}$ & $\begin{array}{l}\text { mudah } \\
\text { didapat } \\
\text { dan dapat } \\
\text { memberika } \\
\text { n rasa } \\
\text { tersendiri }\end{array}$ & & $\begin{array}{l}\text { tidak } \\
\text { berubah } \\
\text { masakan } \\
\text { tradisional } \\
\text { dan } \\
\text { bermanfaat }\end{array}$ \\
\hline & $\begin{array}{l}\text { mudah } \\
\text { dicari dan } \\
\text { tidak } \\
\text { mengeluar } \\
\text { kan biaya }\end{array}$ & $\begin{array}{l}\text { mudah } \\
\text { dicari dan } \\
\text { tidak } \\
\text { mengeluar } \\
\text { kan biaya }\end{array}$ & & lebih enak \\
\hline & $\begin{array}{l}\text { membedak } \\
\text { an antara } \\
\text { bumbu } \\
\text { satu } \\
\text { dengan } \\
\text { bumbu } \\
\text { yang lain } \\
\text { memperta } \\
\text { hankan }\end{array}$ & $\begin{array}{l}\text { membedak } \\
\text { an antara } \\
\text { bumbu } \\
\text { satu } \\
\text { dengan } \\
\text { bumbu } \\
\text { yang lain } \\
\text { mempertah } \\
\text { ankan }\end{array}$ & & $\begin{array}{l}\text { bermanfaat } \\
\text { dan sedap }\end{array}$ \\
\hline
\end{tabular}

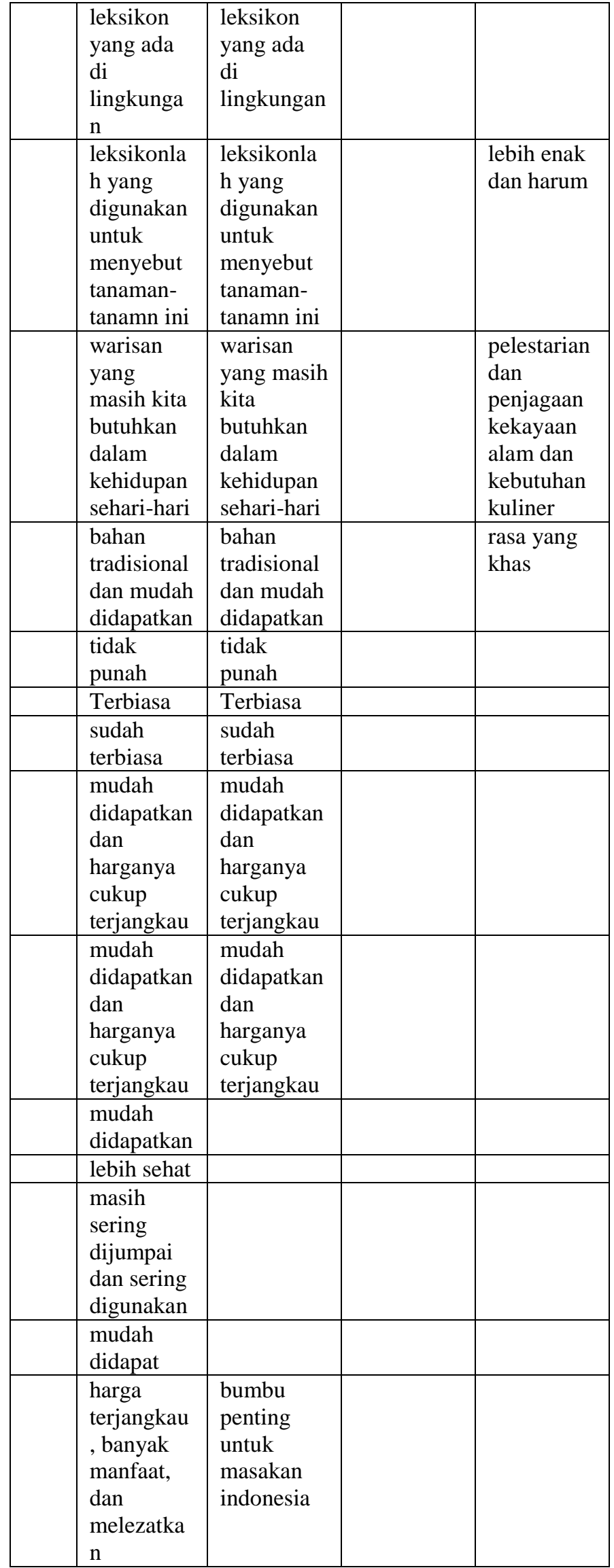




\begin{tabular}{|l|l|l|l|l|}
\hline $\begin{array}{l}\text { biasa } \\
\text { dipakai di } \\
\text { rumah }\end{array}$ & $\begin{array}{l}\text { bumbu } \\
\text { masakan } \\
\text { utama }\end{array}$ & & \\
\hline $\begin{array}{l}\text { ada di } \\
\text { pasar dan } \\
\text { bermanfaa } \\
\text { t bagi } \\
\text { tubuh }\end{array}$ & & & \\
\hline $\begin{array}{l}\text { alami, } \\
\text { tradisional } \\
\text { dan mudah } \\
\text { didapatkan }\end{array}$ & & & \\
\hline $\begin{array}{l}\text { murah dan } \\
\text { mudah } \\
\text { didapatkan }\end{array}$ & & & \\
\hline $\begin{array}{l}\text { yang } \\
\text { utama buat } \\
\text { masakan }\end{array}$ & & & \\
\hline $\begin{array}{l}\text { pemertaha } \\
\text { nan rasa } \\
\text { asli }\end{array}$ & & & \\
\hline
\end{tabular}

yakni bumbu masak tradisional telah tergesar dengan hadirnya bumbu masak instan yang terus menggerus eksistensi bumbu masak tradisional tersebut lewat penetrasi iklan dan membanjinrya bumbu instan di banyak tempat penjualan.

Selanjutnya, dalam pemaknaan tanaman bumbon, terdapat beberapa kesamaan, misal secara sosial, tanaman itu dapat menjalin relasi sosial antara responden dengan masyarakat (petani, penjual, dan keluarga sendiri). Secara ekonomis, tanaman bumbon menghemat uang belanja keluarga dan dapat membantu/meningkatkan taraf hidup petani dan penjual bumbon. Secara ekologis, tanaman bumbon ini melestarikan lingkungan dan lingkungan menjadi semakin asri, alami, indah, sejuk, rindang, sehat, cantik, bersih, ramah lingkungan.

Terakhir, faktor yang mempengaruhi pemertahanan tanaman bumbon oleh keempat kelompok responden bersifat multifaktor, yakni faktor (i) kebiasaan keluarga, (ii) alami, (iii) rasa enak/sedap/harum, (iv) harga murah, (v) mudah diperoleh/didapat, dan sebagainya. Di samping itu, ada faktor yang sangat penting yang diyakini oleh responden, yakni faktor pelestarian lingkungan, penjagaan kekayaan alam, dan pemertahanan leksikon tanaman bumbon. Dengan demikian, faktor-faktor tersebut menunjukkan adanya interrelasi yang sangat erat antara manusia, lingkungan dan keberagaman merupakan tiga hal yang menyatu (tri tunggal) atau trinity yang tak terpisahkan (inseparable).

\section{DAFTAR PUSTAKA}

in dan sebagainya. Di samping itu, ada faktor yan sangat penting, yakni faktor pelestarian lingkungan, penjagaan kekayaan alam, sebagai obat herbal dan pemertahanan leksikon tanaman bumbon.

\section{SIMPULAN}

Dari analisis data di atas ditemukan bahwa responden dari UPGRIS masih mempertahankan leksikon tanaman tradisional untuk bumbu masak (bumbon) sebanyak 24 leksikon (75.00\%) dari 32 leksikon yang diteskan bagi 30 responden. Selanjutnya, mahasiswi dari UNNES menduduki peringkat kedua dengan pemertahanan leksikon bumbon sebanyak 14 leksikon (43.75\%) yang diteskan bagi 21 responden. Peringkat ketiga ditempati oleh responden dari UNIKA dan UNDIP yang hanya mempertahankan 6 leksikon tanaman bumbon $(18,75 \%)$ yang diteskan bagi masng-masing 20 responden. Perhitungan itu didasarkan pada leksikon yang masih dipertahankan oleh seluruh responden, yakni sebanyak 91 responden. Dengan demikian, dapat disimpulkan bahwa pemertahanan leksikon tanaman tradisional untuk bumbu masak (bumbon) mahasiswi Kota Semarang tergolong rendah. Hal ini dapat diartikan bahwa bumbu masak instan telah menggeser bumbu masak tradisional hingga kurang lebih 45\%. Pergeseran itu kemungkinan besar terjadi karena lingkungan tempat tinggal mahasiswi Kota Semarang jarang sekali ditemukan atau sebagian besar bumbu masak tradisional tersebut sudah tidak ditemukan lagi. Kemungkinan selanjutnya adalah bergesernya budaya tradisional ke budaya kontemporer,

al-Gayoni, $\quad$ Yusradi Usman. (2010) "Penyusutan Tutur dalam Masyarakat Gayo: Pendekatan Ekolinguistik." Tesis. Medan: Sekolah Pascarsarjana USU.

Derni, Ammaria. (2008). "The Ecolinguistic Paradigm: An Integrationist Trend in Language Study". The International Journal of Language Society and Culture. Volume 24. Abou Bekr Belkaid University. Halaman 21-30.

Haugen, Einar Ingvald. (1972). The Ecology of Language. Stanford: Stanford University Press.

Hymes, Dell. (1985). Foundations in Sociolinguistics: An Ethnographic Approach. $7^{\text {th }}$ Edition. Philadelphia. University of Pennsylvania Press.

Mbete, Aron Meko. (2009). "Selayang Pandang Tentang Ekolinguistik: Perspektif Kelinguistikan Yang Prospektif”. Bahan untuk Berbagi Pengalaman Kelinguistikan dalam Matrikulasi Program Magister Linguistik Program Pasca Sarjana Universitas Udayana, 12 Agustus 2009.

Subiyanto, Agus. "Ekolinguistik: Model Analisis dan Penerapannya." Dalam Humanika Jurnal Ilmiah 
Kajian http://ejournal.undip.ac.id/index. humanika/article/view/5939.
Humaniora. $\mathrm{php} /$

Sudaryanto. (1993). Metode dan Aneka Teknik Analisis Bahasa. Yogyakarta: Duta Wacana University Press.

Sugiyono. (2014). Metode Penelitian Kuantitatif Kualitatif dan $R \&$ D. Cetakan ke-20. Bandung: Alfabeta.

Wardhaugh, Ronald. (1988). An Introduction to Sociolinguistics. New York: Basil Blackwell Ltd.

Webografi

http://kbbi.kata.web.id/leksikon. Diunduh pada tanggal 25 September http://www.sciencedirect.com/science/article/pii/S038 8000115000352. Diunduh pada tanggal 25 Juni 2017.

Kemdikbud.go.id/entri/leksikon. Diunduh pada tanggal 10 Oktober 2017. https://www.merriamwebster.com/dictionary/sociology. Diunduh pada tanggal 22 Oktober 2017.

http://axcelipa5kelautan.blogspot.co.id/2015/11/25-manfaatdan-kegunaan-bumbu-dapur.html. Diunduh pada tanggal 22 Oktober 2017.

http://www.dosenpendidikan.com/metode-penelitiankualitatif-pengertian-menurut-para-ahli-ciri-tujuan. Diunduh pada tanggal 22 Oktober 2017. 